\title{
Prediction of acid mine drainage formation and zinc migration in the tailings dam of a closed mine, and possible countermeasures
}

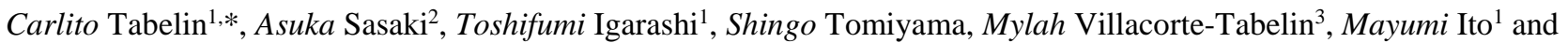 \\ Naoki Hiroyoshi ${ }^{1}$ \\ ${ }^{1}$ Faculty of Engineering, Hokkaido University, Kita 13, Nishi 8, Kita-ku Sapporo 060-8628, Japan \\ ${ }^{2}$ Graduate School of Engineering, Hokkaido University, Kita 13, Nishi 8, Kita-ku Sapporo 060-8628, Japan \\ ${ }^{3}$ Department of Biological Sciences, College of Science and Mathematics, Mindanao State University-Iligan Institute of Technology, A. \\ Bonifacio Avenue, Tibanga, Iligan City 9200, Philippines
}

\begin{abstract}
Acid mine drainage (AMD), the very acidic and highly contaminated leachate generated in closed/abandoned mines, is commonly managed by neutralization to raise the $\mathrm{pH}$ and precipitate most of the heavy metals. Although effective, this approach does not generate any product of economic value, so it is very costly and unsustainable in the long-term. Unfortunately, there are currently no effective alternatives to neutralization, and one way to improve the sustainability of this process is to reduce the volume of AMD generated and/or the concentration of heavy metals. The tailings dam investigated in this study is located in northern Hokkaido, Japan. Detailed characterization of borehole core samples showed that even after almost 40 years of exposure to the environment, the tailings still contain pyrite $\left(\mathrm{FeS}_{2}\right)$ and substantial amounts of copper $(\mathrm{Cu})$ and zinc $(\mathrm{Zn})$. Reactive-transport modeling using Visual MODFLOW predicted that AMD quality would likely continue to deteriorate with time and that treatment should be continued for at least 1,000 years. The model also predicted that a barrier with low permeability installed downstream of the tailings dam or ground sealing techniques for recharge reduction could lower the volume of AMD and concentration of $\mathrm{Zn}$ from the site.
\end{abstract}

\section{Introduction}

Acid mine drainage (AMD) is a serious environmental concern after the closure of mining and mineral processing operations. In the United States, for example, untreated AMD from abandoned mines have contaminated between 15,000 and 23,000 km of streams and rivers [1]. Similarly, AMD is one of the most pressing environmental problems in Japan, an old mining country with over 5,500 closed and abandoned mines [2]. Acid mine drainage is formed when pyrite $\left(\mathrm{FeS}_{2}\right)$, the most common sulfide mineral in the waste rocks and mine tailings, is exposed to oxidizing conditions. Pyrite is resistant to both acidic and alkaline attacks but is rapidly dissolved in the presence of oxidants like dissolved $\mathrm{O}_{2}(\mathrm{DO})$ and ferric ions $\left(\mathrm{Fe}^{3+}\right)$ Eqs. (1) and (2). This process is further enhanced in the natural environment especially under acidic conditions because of the mediation of microorganisms like iron-oxidizing bacteria that generate $\mathrm{Fe}^{3+}$ as a by-product of their utilization of ferrous ions $\left(\mathrm{Fe}^{2+}\right)$ as an energy source Eq. (3) [3]

$$
\begin{gathered}
\mathrm{FeS}_{2(\mathrm{~s})}+3.5 \mathrm{O}_{2(\mathrm{aq})}+\mathrm{H}_{2} \mathrm{O} \rightarrow \mathrm{Fe}^{2+}+2 \mathrm{H}^{+}+2 \mathrm{SO}_{4}{ }^{2-} \\
\mathrm{FeS}_{2(\mathrm{~s})}+14 \mathrm{Fe}^{3+}+8 \mathrm{H}_{2} \mathrm{O} \rightarrow 15 \mathrm{Fe}^{2+}+16 \mathrm{H}^{+}+2 \mathrm{SO}_{4}{ }^{2-} \\
\mathrm{Fe}^{2+}+0.25 \mathrm{O}_{2(\mathrm{aq})}+\mathrm{H}^{+} \rightarrow \mathrm{Fe}^{3+}+0.5 \mathrm{H}_{2} \mathrm{O}
\end{gathered}
$$

Aside from the strong acidity of AMD, it also typically contains various toxic elements (e.g., arsenic (As) and selenium (Se)) and hazardous heavy metals (e.g., copper $(\mathrm{Cu})$, lead $(\mathrm{Pb})$ and zinc $(\mathrm{Zn})$ ) [4]. This is primarily because natural pyrite tends to incorporate a wide variety of elements especially those with similar properties as iron $(\mathrm{Fe})$ and sulfur (S) in its crystal structure, which are also released as a consequence of its dissolution [5], [6].

The most commonly used method to manage AMD is through neutralization, a process wherein basic chemical/substances like limestone or lime are mixed directly with AMD to raise its $\mathrm{pH}$ and precipitate most of the dissolved heavy metals and toxic metalloids. Although cheap and effective in the short-term, it becomes very costly and unsustainable when the treatment stretches for several decades or centuries not only because of the combined costs of neutralization reagents, maintenance of treatment facilities, and sludge disposal but also because neutralization typically does

* Corresponding author: carlito.tabelin@gmail.com 
not generate products of economic value [7]. Unfortunately, there are currently no effective alternatives to neutralization especially in the management of AMD generated from metal-sulfide mines. One way to improve the sustainability of neutralization is to understand how AMD is formed in situ including the migration behavior of heavy metals using reactive-transport modeling. Numerical simulations could predict AMD/groundwater flow paths in the site, estimate how long the generation of AMD would last, and allow for the testing of various countermeasures without doing in situ experiments.

In this study, AMD formation and heavy metal migration in a tailings dam located on the island of Hokkaido, Japan was investigated. Specifically, the objectives of this study are three-fold: (1) to elucidate the hydrological and geochemical characteristics of the tailings dam, (2) to predict AMD formation and heavy metal migration, and (3) to propose possible countermeasures against AMD formation and heavy metal migration. These objectives were achieved by hydrological and geochemical surveys on site, detailed characterization of samples from borehole cores, batch leaching experiments, and reactive-transport modeling using Visual MODFLOW.

\section{Materials and methods}

\subsection{Site description and borehole core sampling}

The tailings dam investigated in this study is located in the northern part of Hokkaido, Japan where an ore body containing gold $(\mathrm{Au})$, silver $(\mathrm{Ag}), \mathrm{Cu}$, cobalt $(\mathrm{Co})$, and $\mathrm{Zn}$ was mined in the past. Acid mine drainage in this site has a pH between 3 and 4, flows at a rate of around 0.04 $\mathrm{m}^{3} / \mathrm{min}$, and contains substantial amounts of dissolved iron $(\mathrm{Fe})(\sim 70 \mathrm{mg} / \mathrm{l}), \mathrm{Cu}(\sim 1 \mathrm{mg} / \mathrm{l}), \mathrm{Zn}(\sim 9 \mathrm{mg} / \mathrm{l})$, and $\mathrm{Pb}$ $(\sim 0.06 \mathrm{mg} / \mathrm{l})$. It is mostly generated from the tailings dams and underground mine workings and has been treated by neutralization since the 1970s. Fig. 1 shows the plain and cross-sectional views of the tailings dam including the location of borehole core samples. The tailings dam is divided into three sections and is located between a stream and a hill.

\subsection{Characterization, leaching experiments, and chemical analyses}

Although four borehole cores were collected on site, only B2, the borehole that transected the tailings, was characterized in detail. Samples from each distinct lithological feature of the borehole core were collected, air-dried in the laboratory, lightly crushed with an agate mortar and pestle, and then sieved through a $2 \mathrm{~mm}$ aperture screen. For the chemical and mineralogical analyses, the samples were further ground to $<50 \mu \mathrm{m}$, and then analyzed by an X-ray fluorescence spectrometer (XRF, Spectro Xepos, Rigaku Corporation, Japan) and X-ray diffractometer (XRD, MultiFlex, Rigaku Corporation, Japan).
The leaching experiments were conducted by mixing $10 \mathrm{~g}$ of sample $(<2 \mathrm{~mm})$ and $200 \mathrm{ml}$ of deionized (DI) water $(18 \mathrm{M} \Omega \cdot \mathrm{cm}$, Milli-Q® Integral Water Purification System, Merck Millipore, USA) in a reciprocal shaker at $200 \mathrm{rpm}$ under ambient conditions. This leaching method is based on the Japanese standard leaching test for contaminated soils [8]. After $6 \mathrm{~h}$, the $\mathrm{pH}$ and oxidationreduction potential $(\mathrm{Eh})$ of suspensions were measured and the leachates were collected by filtration through $0.45 \mu \mathrm{m}$ syringe-driven membrane filters (Millex®, Merck Millipore, USA), which were acidified $(\mathrm{pH}<2)$ and stored at $6^{\circ} \mathrm{C}$ prior to the chemical analyses. Dissolved $\mathrm{Fe}, \mathrm{Cu}, \mathrm{Zn}$, and $\mathrm{Pb}$ were quantified using an inductively coupled plasma atomic emission spectrometer (ICP-AES, ICPE-9000, Shimadzu Corporation, Japan) while coexisting ions like $\mathrm{SO}_{4}{ }^{2-}$ was analyzed by ion chromatography (ICS-1000, Dionex Corporation, USA). The margins of error of the ICP-AES and ion chromatography are approximately $\pm 2 \%$.

(a)

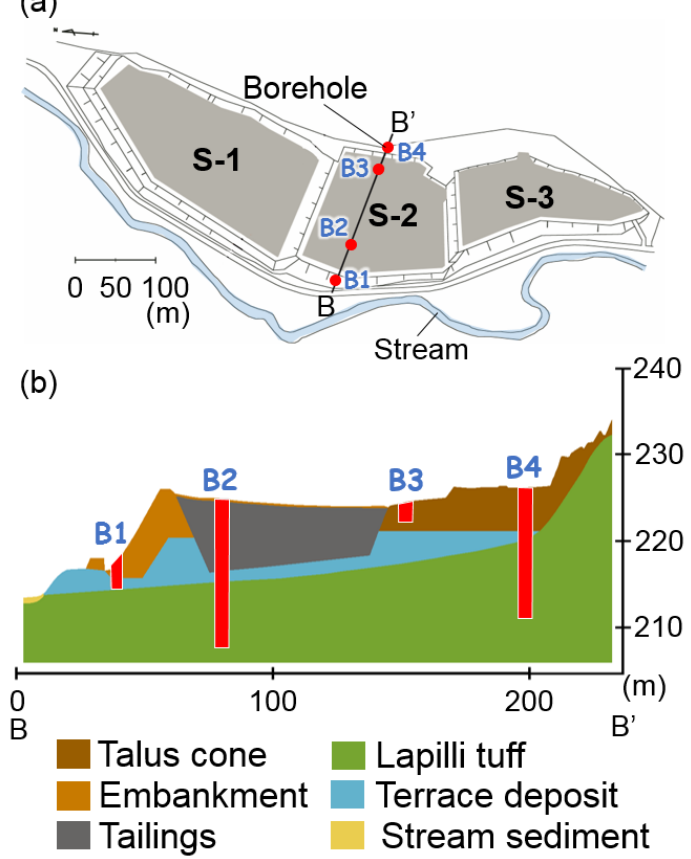

Fig. 1. (a) Plain view of the tailings dam, and (b) crosssectional view of line B-B'.

\subsection{Reactive-transport modeling}

MODFLOW was used to simulate AMD formation and flow paths in the tailings dam including the migration of heavy metals. In addition, possible countermeasures like barriers with low permeability and recharge reduction were evaluated using the model. Fig. 2 shows the twodimensional model of the tailings dam formulated based on the cross-sectional line B-B' in Fig. 1 and the measured hydraulic conductivity $(K)$ and $\mathrm{Zn}$ distribution coefficient $\left(K_{d}\right)$ of each distinct lithological feature. In all simulations, MODFLOW 2005 and MT3DMS were used to model AMD/groundwater flow and solute migration, respectively.

For the simulation of AMD/groundwater flow, the condition was assumed to be in a steady state. The porosity was estimated at around 0.4 based on laboratory 
experiments while particle densities of the tailings and other sediments were equal to 2.80 and $2.65 \mathrm{~g} / \mathrm{cm}^{3}$, respectively. Boundary conditions were set as follows: no flow at the bottom and right side, $300 \mathrm{~mm} / \mathrm{year}$ of effective precipitation, which corresponds to about onethird of precipitation at the site, at the upper part, and constant river head at the left side. The effective precipitation was calibrated by comparing simulated groundwater levels with those measured on site.

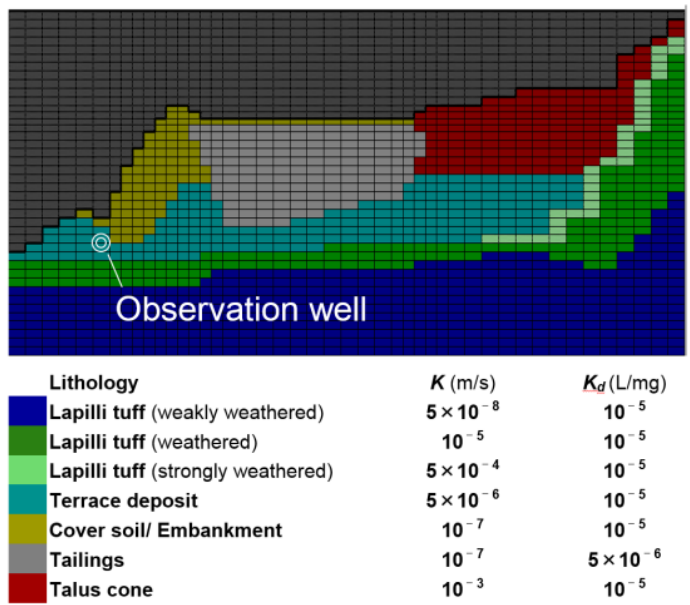

Fig. 2. A two-dimensional model of the tailings dam and properties of its lithological features.

Unsteady-state solute migration was simulated based on the steady-state flow. Zinc was selected as a representative heavy metal for the simulation because it had the highest concentration in the batch leaching experiments and is more mobile compared with the other heavy metals. Migration of $\mathrm{Zn}$ was calculated based on the following equation:

$$
\frac{\partial\left(\theta C^{k}\right)}{\partial t}=\frac{\partial}{\partial x_{i}}\left(\theta D_{i j} \frac{\partial C^{k}}{\partial x_{j}}\right)-\frac{\partial}{\partial x_{i}}\left(\theta v_{i} C^{k}\right)+q_{s} C_{s}^{k}+\sum R_{n}
$$

where $C^{k}$ is the concentration of the solute $k\left[\mathrm{MT}^{-3}\right], \theta$ is the porosity [-], $t$ is time [T], $x_{i}$ and $x_{j}$ are the distances in $i$ and $j$ directions [L], respectively, $D_{i j}$ is the dispersion coefficient $\left[\mathrm{L}^{2} \mathrm{~T}^{-1}\right], v_{i}$ is the interstitial velocity $\left[\mathrm{LT}^{-1}\right], q_{s}$ is the volumetric flow per unit volume $\left[\mathrm{T}^{-1}\right], C_{s}{ }^{k}$ is the flux concentration of solute $k\left[\mathrm{ML}^{-3}\right]$, and $\Sigma R_{n}$ is the reaction term. The first, second, third, and fourth terms on the right side of Eq. (4) represent dispersion, advection, sink/source, and reaction, respectively. Eq. (4) can be simplified to Eq. (5) by neglecting the effects of sink/source (i.e., third term) and assuming that reaction (i.e., fourth term) of the target solute $k$ followed the linear adsorption isotherm.

$$
R \theta \frac{\partial(\theta C)}{\partial t}=\frac{\partial}{\partial x_{i}}\left(\theta D_{i j} \frac{\partial C}{\partial x_{j}}\right)-\frac{\partial}{\partial x_{i}}\left(\theta v_{i} C\right)
$$

$R$ in Eq. (5) is the retardation factor given by the following equation:

$$
R=1+\frac{\rho_{b}}{\theta} K_{d}
$$

where $\rho_{b}$ is the bulk density $\left[\mathrm{ML}^{-3}\right]$, and $K_{d}$ is the distribution coefficient $\left[\mathrm{L}^{3} \mathrm{M}^{-1}\right]$. The $K_{d}$ values of each lithological feature of the tailings dam were determined in the laboratory by measuring the solid-liquid concentration ratios using potassium chloride solution (Fig. 2). Dispersivity values in the $i$ and $j$ directions were set at $10 \mathrm{~m}$ while the initial concentrations of $\mathrm{Zn}$ are 40 $\mathrm{mg} / \mathrm{l}$ in the tailings and $0 \mathrm{mg} / \mathrm{l}$ elsewhere. This initial $\mathrm{Zn}$ concentration in the tailings was based on the maximum $\mathrm{Zn}$ concentration of the porewater measured on site. An observation well was set in the model around the embankment near the stream to understand AMD formation and the migration of $\mathrm{Zn}$ from the tailings dam (Fig. 2). The effectiveness of a barrier with low permeability (hydraulic conductivity $=10^{-8} \mathrm{~m} / \mathrm{s}$ ) and recharge reduction to lower the concentration of $\mathrm{Zn}$ and limit the formation of AMD was also evaluated using the reactive-transport model.

\section{Results and discussion}

\subsection{Characterization of samples from the tailings dam}

Tailings were located between about 0.3 and $8.3 \mathrm{~m}$ below the ground surface. A thin soil cover was observed with a depth of about $0.3 \mathrm{~m}$ while lithological features underneath the tailings consisted of about $1.5-\mathrm{m}$ thick terrace sediments and the basement rock (lapilli tuff), which extends downwards from a depth of around $10 \mathrm{~m}$. The samples collected from the tailings are mainly composed of quartz $\left(\mathrm{SiO}_{2}\right)$ and chamosite $\left(\left(\mathrm{Fe}_{5} \mathrm{Al}\right)\left(\mathrm{AlSi}_{3}\right) \mathrm{O}_{10}(\mathrm{OH})_{8}\right)$, a phyllosilicate mineral of the chlorite group commonly found in hydrothermally altered zones, with minor amounts of pyrite and gypsum $\left(\mathrm{CaSO}_{4} \cdot 2 \mathrm{H}_{2} \mathrm{O}\right)$. In comparison, the covering soil, terrace sediments, and lapilli tuff only contained silicates/phyllosilicates and feldspars (i.e., sanidine and labradorite). The presence of pyrite in the tailings is also evident in the substantial amounts of $\mathrm{Fe}(18-28 \%$ as $\mathrm{Fe}_{2} \mathrm{O}_{3}$ ) and $\mathrm{S}(4-9 \%)$. The heavy metal content of tailings is very high especially those of $\mathrm{Zn}$ and $\mathrm{Cu}$ at around $2,900-22,300$ and $1,400-6,500 \mathrm{mg} / \mathrm{kg}$, respectively. The As content $(10-65 \mathrm{mg} / \mathrm{kg})$ of the tailings is not particularly high considering that it contains substantial amounts of pyrite. These results suggest that even after more than 40 years of exposure to the environment, AMD generation and the release of heavy metals would likely persist on site because the tailings still contain substantial amounts of pyrite and heavy metals. 


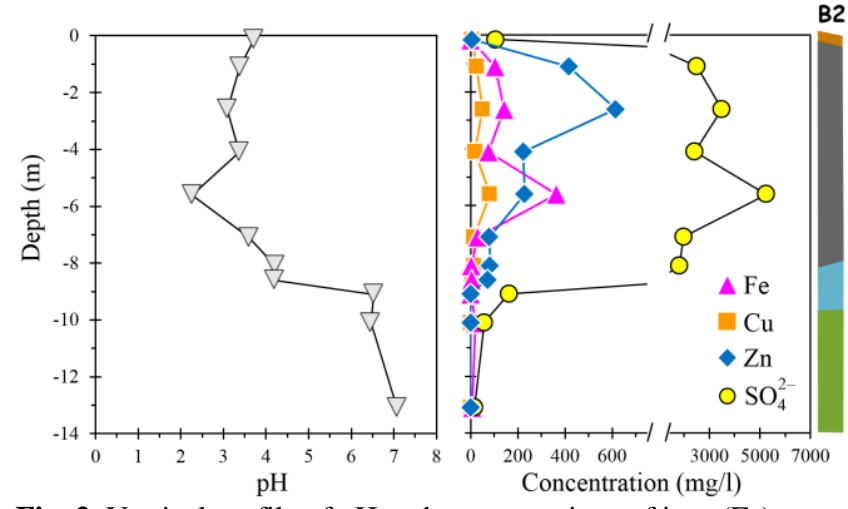

Fig. 3. Vertical profile of $\mathrm{pH}$ and concentrations of iron $(\mathrm{Fe})$, copper $(\mathrm{Cu})$, zinc $(\mathrm{Zn})$ and sulfate $\left(\mathrm{SO}_{4}{ }^{2-}\right)$.

Fig. 3 shows the vertical profile of $\mathrm{pH}$ and the concentrations of $\mathrm{Cu}, \mathrm{Zn}, \mathrm{Cu}$, and $\mathrm{SO}_{4}{ }^{2-}$ from the leaching experiments. Standard leaching tests typically show the most soluble contaminants in a particular sample [4]. In other words, the conditions of this test simulate the effects of rain and groundwater on the samples [9], [10]. Acidic $\mathrm{pH}$ was measured in the leachates of samples from the covering soil, tailings, and the upper part of the terrace deposit, suggesting that AMD slightly penetrated the terrace deposit layer underneath the tailings. In terms of the heavy metals, the highest concentrations of $\mathrm{Fe}(3-370 \mathrm{mg} / \mathrm{l}), \mathrm{Cu}(14-82$ $\mathrm{mg} / \mathrm{l})$, and $\mathrm{Zn}(82-615 \mathrm{mg} / \mathrm{l})$ were measured in the samples from the tailings. Among these three, $\mathrm{Zn}$ appears to be the most easily mobilized as suggested by its high concentration not only in the tailings but also from the upper part of the terrace deposit layer. The concentration of $\mathrm{SO}_{4}{ }^{2-}$ was also very high in the tailings, which is to be expected because it is one of the main products of pyrite oxidation Eqs. (1) and (2) [11], [12]. It is interesting to note that the low permeability of the terrace deposit sufficiently limited the migration of AMD downwards, which is consistent with the low $\mathrm{SO}_{4}{ }^{2-}$ concentration and circumneutral $\mathrm{pH}$ values measured in the bottom part of the terrace deposit layer and the underlying lapilli tuff basement rock. However, the upper part of the terrace deposit layer already showed signs of significant weathering due to more than 40 years of exposure to AMD.

\subsection{AMD/Groundwater flow, migration of zinc, and possible countermeasures}

One important assumption of the reactive-transport model used in this study is that $\mathrm{Zn}$ in the tailings is partitioned into not only easily soluble phases but also the other fractions, the effects of which are expressed in $K_{d}$. The model predicted that AMD/groundwater flow in the tailings dam would follow areas with higher hydraulic conductivities where water flow encounters the least resistance (Fig. 4).
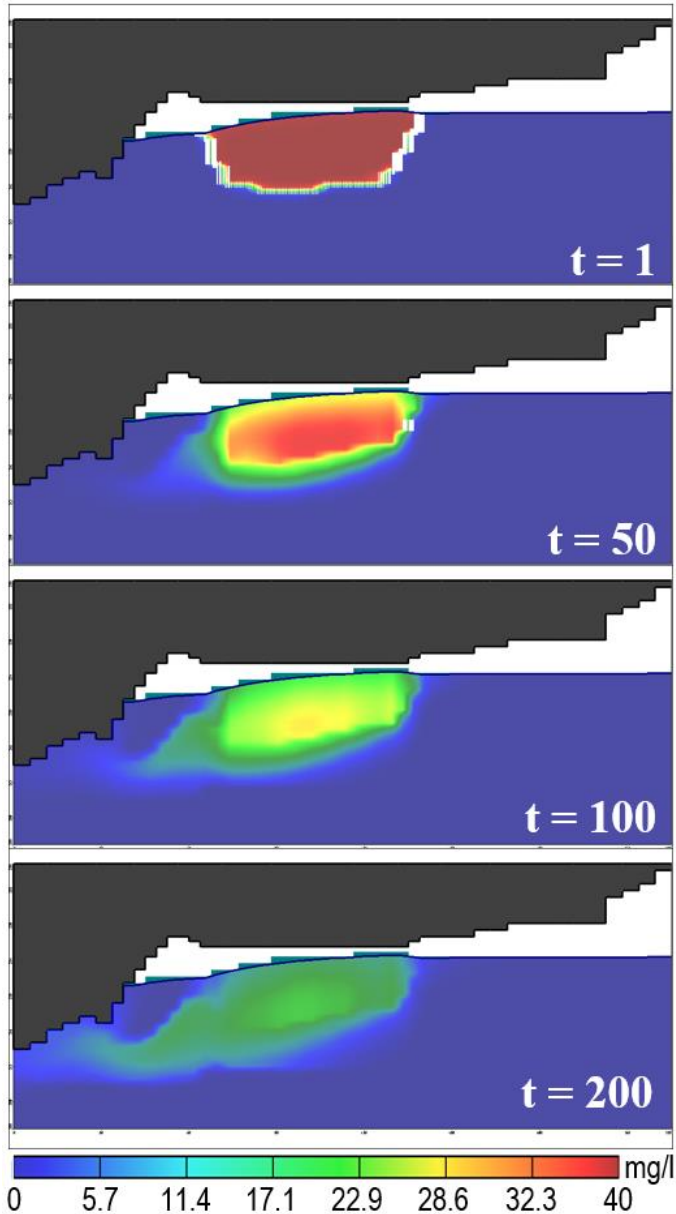

Fig. 4. AMD/groundwater flow in the tailings dam at 1, 50, 100 , and 200 years.

It also predicted that $\mathrm{Zn}$ concentration would continue to increase with time, indicating that the quality of AMD on site would likely deteriorate more in the future. The environmental standard of Japan for dissolved $\mathrm{Zn}$ in effluents is $1 \mathrm{mg} / \mathrm{l}$, which means that neutralization in this site should be continued for at least 1,000 years (Fig. 5(a)).

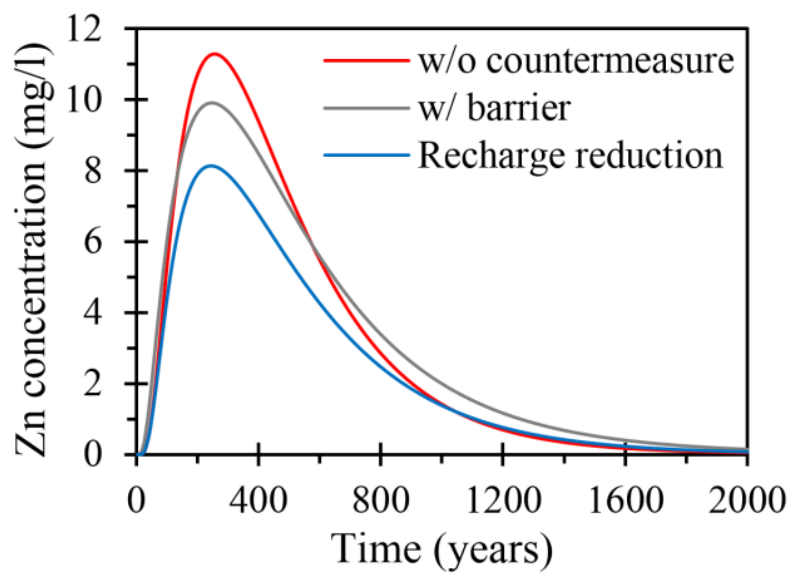

Fig. 5. Predicted zinc ( $\mathrm{Zn})$ concentration change with and without countermeasures. 
Two types of possible countermeasures were evaluated using the model: (1) a barrier with low permeability $\left(K=10^{-8}\right)$ downstream of the tailings dam, and (2) recharge reduction on-site via ground covering techniques of key recharge areas. Installing a barrier with low permeability effectively delayed the migration of $\mathrm{Zn}$ as illustrated by its lower peak concentration in Fig. 5, but as a consequence, $\mathrm{Zn}$ concentration after ca. 600 years became higher than that without any countermeasure. Lowering the recharge rate from 300 to $100 \mathrm{~mm} /$ year showed better results because it decreased the $\mathrm{Zn}$ concentration until the end of the simulation. Based on these results, AMD generation and the release of heavy metals from tailings dams could be limited by installing barriers and ground covers on key areas of the site. For example, covering the tailings with materials with low permeability $\left(K=10^{-8}\right)$ resulted in an AMDvolume reduction of around $24 \%$.

\section{Conclusion}

This study investigated AMD generation and $\mathrm{Zn}$ migration in a tailings dam and proposed possible countermeasures to reduce AMD volume and lower the concentration of $\mathrm{Zn}$. The results of this study are summarized as follows:

1. The tailings still contained substantial amounts of pyrite and heavy metals like $\mathrm{Fe}, \mathrm{Cu}$, and $\mathrm{Zn}$ even after over 40 years of exposure to the environment.

2. Among the heavy metals found in the tailings, $\mathrm{Zn}$ was the most easily mobilized and had the highest concentration.

3. The reactive-transport model predicted that AMD formation and heavy metal release would likely continue for at least 1,000 years.

4. Acid mine drainage formation and the release of heavy metals could be limited by installing a barrier with low permeability downstream of the tailings dam or via ground covering techniques for recharge reduction.

The authors wish to thank the Japan Society for the Promotion of Science (JSPS) grant-in-aid for scientific research (KAKENHI) (Grant numbers: JP26289149 and JP17K12831) for the financial support.

\section{References}

[1] Ferguson, K.D., and Erickson, P.M., Pre-mine prediction of acid mine drainage, In Environmental Management of Solid Waste (pp. 24-43). Berlin, Springer, 1988.

[2] Herrera, P., Uchiyama, H., Igarashi, T., Asakura, K., Ochi, Y., Iyatomi, N. and Nagae, S., Treatment of acid mine drainage through a ferrite formation process in central Hokkaido, Japan: Evaluation of dissolved silica and aluminium interference in ferrite formation, Miner. Eng. 20, 2007, 1255-1260.

[3] Singer, P.C. and Stumm, W., Acidic mine drainage: the rate-determining step, Science 167, 1970, 11211123.

[4] Tabelin, C.B., Igarashi, T., Villacorte-Tabelin, M., Park, I., Opiso, E.M., Ito, M. and Hiroyoshi, N., Arsenic, selenium, boron, lead, cadmium, copper, and zinc in naturally contaminated rocks: A review of their sources, modes of enrichment, mechanisms of release, and mitigation strategies, Sci. Total Environ. 645, 2018, 1522-1553.

[5] Abraitis, P.K., Pattrick, R.A.D. and Vaughan, D.J., Variations in the compositional, textural and electrical properties of natural pyrite: A review, Int. J. Miner. Process. 74, 2004, 41-59.

[6] Tabelin, C.B., Igarashi, T., Tamoto, S. and Takahashi, R., The roles of pyrite and calcite in the mobilization of arsenic and lead from hydrothermally altered rocks excavated in Hokkaido, Japan, J. Geochem. Explor. 119-120, 2012, 17-31.

[7] Ueda, H. and Masuda, N., An analysis on mine drainage treatment cost and the technical development to prevent mine pollution, Shigen-toSozai, 121, 2005, 323-329. (In Japanese with English abstract)

[8] Tabelin, C.B., Hashimoto, A., Igarashi, T. and Yoneda, T., Leaching of boron, arsenic and selenium from sedimentary rocks: I. Effects of contact time, mixing speed and liquid-to-solid ratio, Sci. Total Environ. 472, 2014, 620-629.

[9] Tabelin, C.B., Igarashi, T. and Takahashi, R., Mobilization and speciation of arsenic from hydrothermally altered rock in laboratory column experiments under ambient conditions, Appl. Geochem. 27, 2012, 326-342.

[10] Tabelin, C.B., Sasaki, R., Igarashi, T., Park, I., Tamoto, S., Arima, T., Ito, M. and Hiroyoshi, N., Simultaneous leaching of arsenite, arsenate, selenite, and selenate, and their migration in tunnelexcavated sedimentary rocks: I. Column experiments under intermittent and unsaturated flow, Chemosphere 186, 2017, 558-569.

[11] Tabelin, C.B. and Igarashi, T., Mechanisms of arsenic and lead release from hydrothermally altered rock, J. Hazard. Mater. 169, 2009, 980-990.

[12] Tabelin, C.B., Veerawattananun, S., Ito, M., Hiroyoshi, N. and Igarashi, T., Pyrite oxidation in the presence of hematite and alumina: Batch leaching experiments and kinetic modeling calculations, Sci. Total Environ. 580, 2017, 687689. 